\title{
Competition and Banking Efficiency in the CEMAC Zone
}

\author{
Paul Ningaye ${ }^{1}$, Madaha Yemetio Mathilde ${ }^{1} \&$ Nembot Ndeffo Luc ${ }^{1}$ \\ ${ }^{1}$ Faculty of Economics and Management, University of Dschang, Cameroon \\ Correspondence: Paul Ningaye, Faculty of Economics and Management, University of Dschang, PO Box 110 \\ Dschang, Cameroon. Tel: 237-7757-8161 or 237-9549-6670. E-mail: paningaye@yahoo.fr
}

Received: March 4, 2014

doi:10.5539/ijef.v6n6p127
Accepted: March 19, 2014

Online Published: May 25, 2014

URL: http://dx.doi.org/10.5539/ijef.v6n6p127

\begin{abstract}
The objective of this study is to analyze the effect of competition on the cost and profit efficiency of banks in the Economic and Monetary Community of Central Africa (CEMAC), over the period 2003-2010. The analysis is done in two stages. First, the stochastic frontier approach (SFA) permits us to estimate the efficiency scores and the competition levels measured by the adjusted Lerner index. Second, the competition measures thus obtained, and a set of control variables are introduced into a panel model to explain the cost and profit efficiencies. The results show that competition has been favorable to the profit efficiency, but not to the cost efficiency. This is because the diversification and the debtors' prime rates have evolved in the expected way. However, the creditors' prime rate, bank loans, inflation and the Gross Domestic Product (GDP) have evolved in an unexpected way. We recommend promotion of growth and a better inflation control by the government. As to the banks, they will gain from greater diversification of their products.
\end{abstract}

Keywords: bank competition, cost efficiency, profit efficiency, adjusted lerner index

\section{Introduction}

Given that the capitals market is embryonic in the CEMAC zone, indirect funding including bank loans, remains the main means of financing its economy (Hicks, 1974; Fouda, 2009). The banking system therefore provides almost all the financial intermediation role in this zone. It is therefore of great interest to seek its efficiency because efficient banks have the capacity to increase their outputs without increasing inputs, or reduce their inputs without reducing outputs (Chen et al., 2005). They also have the capacity to make maximum profit for a given level of input and output prices (Claessens \& Laeven, 2004). By these characteristics, an efficient banking system can stimulate economic growth in the region through technological innovation (Brou, 2010), financial innovation(Kane, 1988; Sobreira, 2004) and the effectiveness of production factors (Levine, 1997).

Competition is seen by many authors as the simplest way to ensure the efficiency of banks. According to them, it generates a low intermediation cost; which increases the volume of savings and investments, and revives the economic growth (Rhoades \& Rutz, 1982). However, the banking market structure of CEMAC has been profoundly modified towards greater competition, due to the 1980 s banking crisis. It manifested itself by a strong tension of treasury, an accumulation of deficit management balances, significant irrecoverable funds and an almost negative banking profitability ratio closer to zero in all the CEMAC States. Consequently, 9 out of 40 banks in this zone had stopped their activities: only one complied with all regulatory standards, 14 had precarious balances and 16 were insolvent (BEAC, 2002).

The measures taken to deal with this situation sought greater competition in the sector; not only through the number of banks, but also through the entry conditions which are the main indicators of competition in the banking industry according to Baumol and al. (1982). These measures were: (i) the removal of credit squeeze, (ii) the privatization or closure of public banks as well as the withdrawal of the State capital from the banking sector, (iii) the latitude granted to banks to negotiate prime rates with their clients within the Maximum Debtor prime Rate (MDR) and the Minimum Creditor prime Rate (MCR) adopted by the BEAC, (iv) the total liberalization of the inter-banking market rate, (v) free access into the national financial system through foreign participation to the capital of national banks, on the one hand, and through the establishment of foreign banks in the national financial system, on the other, (vi) the creation of COBAC followed by the Harmonization of the Banking Regulations in Central Africa, to control the banking activity and to provide a more reassuring legal environment. The implementation of all these measures was effective from 1993 with the start-up of COBAC. 
Conversely, the theory of destructive competition supports that competition is incompatible with banking efficiency. According to Chiappori and Yanelle (1996), Pruteanu-Podpiera et al. (2008), and Casu and Girardon, (2009), by reducing prices, increasing creditors' prime rates and reducing debtors' prime rates reduces banks margin and constrains them to take excessive risks.

The objective of this research is to identify the relationships between banking concentration and the efficiency of banks in the CEMAC zone over the period 2003-2010. In effect, it is from 2003 that one notices an increase in the number of banks in the zone. The methodology consists of two parts. First, the stochastic frontier approach (SFA) is used to make estimates on the cost and profit functions, so as to obtain the efficiency scores and the levels of competition through the adjusted Lerner index. Second, the competition measures obtained and a set of control variables explain the cost and profit by panel regressions.

The rest of the work is articulated as follows: section 2 presents the different theoretical bases of the relationships between competition and efficiency. Section 3 discusses the competition and efficiency measures adopted. Section 4 presents the methodology. Section 5 presents the results and discussion and Section 6 is devoted to the conclusion with recommendations of policies.

\section{Bank Competition and Efficiency}

The authors who establish the relationship between competition and banking efficiency generally draw inspiration from the model Structure-Behavior-Performance (SBP) (Dietsch, 1992; Neuberger, 1997), which has constituted for a long time the theoretical model of industrial organization in general; and in particular, of the banking industry. This model postulates that the structure of any market is characterized by the number of suppliers and buyers, the diversity of products, the forms of integration, the price structure and the entry barriers. This structure determines behaviors in terms of pricing, product selection and strategy. These behaviors in turn determine the results in terms of efficiency, margins and profits. But due to the peculiar nature of the banking market; characterized by the asymmetry of information and economies of scale, the SBP model could be reduced to the effects of the entry conditions on the degree of concentration, and the impact of concentration on the margins and on the prices (Dietch, 1992; Neuberger, 1997).

Drawing inspiration from the SBP paradigm, several authors have given diverse arguments to establish a positive theoretical relationship between competition and the efficiency of banks. Hart (1983) and Leibenstein (1966) show that competition implies greater efficiency because it helps to reduce mismanagement. Managers actually run the risk of being run over by their competitors or of being fired by the proprietors. Koetter and Vins (2008) explain that the greater the market power; that is lack of competition, the less will be the effort to maximize profits without necessarily having efficiency. According to Rhoades and Rutz (1982), Claessens and Laeven (2004), the existence of the market power in the banking sector generates a high intermediation cost. This leads to high prices, low volume of savings and investments; with a reduction in economic growth.

Empirical studies on the positive relationship between competition and efficiency of banks are those of: Berger and Hanan (1998) on a sample of 5,000 U.S. banks, Delis and Tsionas (2009) on a sample of banks from 11 countries of the European Union and the United States over the period 2000-2007, Koetter and Vins (2008) on a sample of 457 German banks over the period 1994-2006 and Cocoresse Pellechia (2010) on a sample of 714 Italian banks over the period of 1992-2007. These theoretical and empirical works explain that competition increases bank efficiency through a reduction in the prices of banking services, a rise in the creditors' prime rates, a drop in the rates of debtors with a consequent increase in bank contribution to the economy in form of loans (Berger \& Hanan, 1998; Claessens \& Laeven, 2004). These transmission channels will enable the authors to discuss the results of this research.

The SBP model was questioned in particular by the theory of contestable markets (Baumol et al., 982); which states that the level of competition is not determined by the number of firms present in the market, but by the entry and exit conditions of the industry. Thus, competitive prices can be practiced even in a market where there are only two companies, if potential entrants constitute a threat to these firms. Peltzman (1977) has also showed that efficiency can cause managers to reduce costs and not the concentration through market power. But the negative relationship between competition and bank efficiency was explicitly established by the theory of destructive competition (Baltensberger \& Dermine, 1990; Diestsch, 1992, Chiappori \& Yanelle, 1996). This theory explains that a drop in prices and of debtors' rates, a rise in creditors' prime rates resulting from bank competition benefit consumers, but are destructive to the banks. Thus, small banks go bankrupt and those that resist produce at a loss while waiting to use their excess capacity. Following this logic, Marquez (2002), Hauswald and Marquez (2006) show that competition has a negative effect on bank efficiency due to the specificity of the banking market. The bank's efficiency lies on the bank's capacity to collect information and 
monitor at a low cost. Yet competition leads to dispersion of information and several banks have information on a little number of borrowers. This generates inefficiency because many people who are not qualified to borrow end up having access to credit, and lending decisions become less efficient.

Empirical works on the negative effects of banking competition in relation to efficiency are those of: Weill (2004) and Maudos and De Guevera (2007) on a sample of banks in the European Union over the periods 1994-1999 and 1993-2002, respectively, Pruteanu-Podpiera and al. (2008) on a sample of Czech banks between 1994 and 2005, Girardon and Casu (2009) on the banks of five European countries over the period 2000-2005, IdriesHishman (2009) on a sample of 16 banks operating in Jordan over the period 2001-2005, and Williams (2011) on a sample of 419 commercial banks in Latin America over the period 1988-2008 . Asma et al. (2012) establish the existence of a positive relationship between the increase of competition and efficiency (estimated by SFA) for the Tunisian banking industry, over the period 1990-2009, on a sample of Tunisian banks. For these works, it is the concentration; that is lack of competition, which increases efficiency for the following reasons: (i) it reduces transaction and monitoring costs with the firms, (ii) it allows banks to achieve more profit and thus have an incentive to act prudently (there is improvement in bank stability), (iii) it allows banks to be less under pressure to improve the quality of banking services: this reduces operational costs and increases their cost efficiency.

Whatsoever are the results at the end, the empirical studies measured competition by the Lerner index or the adjusted Lerner index. The efficiency frontier is estimated from two outputs (loans and deposits) and 02 inputs (labor and physical capital). At times, three inputs are considered (deposits, labor and capital) against a single output which is the value of total assets. The estimation method of this frontier is either parametric or nonparametric.

\section{The Research Setting}

\subsection{Discussion of Competition Measures and Adopted Efficiency}

The model of perfect competition which assumes among others the free entry and exit in a market is not applicable to the banking industry due to entry barriers (costs for new entrants or regulation) and non-recoverable costs (sunk costs). These are costs that will generate gains for the company over a long period, but that cannot be recovered if it decides to leave the market (Freixas \& Rochet, 2010). It then becomes necessary to quantify the level of competition in a banking system so as to follow its evolution.

Structural measures of competition are based on the concentration indices. A concentration index is the weighted sum of the market shares of the different banks in a country by the weight of each bank. Because of this simplicity of calculation, the concentration indices are numerous and differ depending on the weights given (see Bikker \& Haaf, 2002). Nevertheless, these measures are imperfectly related to competition because they are influenced by a number of factors such as the macroeconomic environment, the form and level of taxation of financial intermediaries and the bank specific factors such as the operation scale and the preference for risk (Claessens \& Laeven, 2004).

Non-structural measures try to quantify the level of competition of each bank. There are of two types. In the first place, the model developed by Breshnahan (1989) uses the terms of profit maximization under perfect competition. The estimated parameter of this model provides a measure of the degree of competition, which varies from pure and perfect competition to monopoly. In the second place, there is the Panzar and Rosse model based on the extent to which a change in input prices influences the revenue obtained by a specific bank. The measurement of competition obtained; denoted $(\mathrm{H})$, is between minus infinity and one. $\mathrm{H}<0$, we have a monopoly. $0<\mathrm{H}<1$ is a monopolistic competition and lastly $\mathrm{H}=1$ we have a perfect competition. In the third place, we have the Lerner index of the market power (Lerner, 1934; Koetter et al., 2008); which is based on the social loss due to monopoly that is, the difference between prices and the marginal cost. On the algebraic level, it is defined as the ratio of the difference between the price charged by the firm and its marginal cost by the price. It is inversely proportional to the competition. This is the Lerner index that is applied in this research.

As to the concept of efficiency, it is broadly defined as the capacity of an organization, firm or decision unit, to increase its output without increasing inputs or to reduce its inputs without reducing its output (Chen et al., 2005). A bank will be said to be efficient if it best uses its resources to satisfy the needs of its customers. As the customers' needs and resources are diversified, one can distinguish several types of efficiency in the banking industry. The efficiency scale is related to the optimal choice of the output of the bank, while the efficiency range is related to the optimal choice of product mix (Berger et al., 1993). The efficiency- X (Berger, Hunter, \& Timme, 1993) can be subdivided into cost efficiency, standard profit efficiency and alternative efficiency profit, considered as the three most important economic concepts of efficiency (Berger \& Mester, 1997). Also called 
economic efficiency, the cost efficiency is the capacity to produce a quantity of output at minimum cost; given the prices of input (Farrell, 1957). The efficiency scores are between 0 and 1.

A cost efficiency score of 0.75 or $75 \%$ means that the bank uses $25 \%$ of cost more than the company with good practice confronted with the same conditions. It can therefore produce the same amount of output by performing a $25 \%$ reduction in costs. But by studying the cost efficiency only, inefficiency of the demand side is neglected. The profit function incorporates both the cost of input choice effect and the income effect of the choice of the output: hence the importance of efficiency profit (Berger \& Mester, 1997).

Two types of efficiency profit are retained in the literature. The standard profit efficiency measures the ability of the bank to produce a maximum of possible profit for a given level of input and output prices. It thus takes into account the inefficiency that could come from the demand side (output prices). A score of $70 \%$ indicates that the company loses $30 \%$ of the profit which it could have obtained; due to excessive cost, low income, or both. Humphrey and Pulley (1997) propose alternative profit efficiency, which measures the ability of a firm to obtain the maximum possible profit, given the prices of inputs and the level of output; instead of the output price like in the standard profit. Alternative profit efficiency is more convenient to the situation of the CEMAC because it rests on the assumption that output prices are not accurately measured.

Whatever the efficiency adopted, its measure consists of placing the bank in relation to the frontier of good practices. This frontier can be estimated following the non-parametric approach and the parametric approach. The nonparametric approach has the advantage of not requiring a functional form of efficiency frontiers. As limit, the distance between the position of the bank and the frontier is attributed to inefficiency. All the same, there may be errors. Moreover, it is more suitable for small samples. The most widely used non-parametric method is the DEA (Data Envelopment Analysis) method (Farell, 1957; Charnel et al., 1978). It uses the technique of linear programming to determine a boundary so that firms located on the border are called efficient, while those found within the boundary are called inefficient. The parametric approach has for advantage the modeling of the term of inefficiency error. As limit, there is need of a functional form of production or of cost where choice does not cause unanimity.

The Cobb Douglas specification assumes homogeneity of aggregate output and the constant return to scale. These restrictions explain why it is abandoned in favor of the translog specification, which does not necessitate a prior recourse to particular hypotheses (Dem, 2003). It corresponds to the need of the banking industry, which is a multiproduction and where there is a growing yielding scale (From Devezeaux Lavargne et al., 1990; Heyer et al., 2004). For this reason, the translog specification is adopted in this research. Once the functional form is specified, the problem of estimation method appears. One has the choice between the Thick Frontier Approach, the Distribution Free Approach and the Stochastic Frontier Approach (SFA). Only the latter method namely SFA permits estimates of the efficiency of each bank (and thus, of each country) using its own inputs and outputs. As this is approach is more appropriate for the pursuit of our goals, we have adopted it.

\subsection{The CEMAC Banking System}

Table 1 presents some characteristics of the banking system of the CEMAC and their evolution during the period of study. The upward trend in the number of banks is related to the measures taken by the monetary authorities to encourage banking competition.

Table 1. Some indicators of the characteristics of the banking system

\begin{tabular}{lllllllll}
\hline & $2003 \pm$ & 2004 & 2005 & 2006 & 2007 & 2008 & 2009 & 2010 \\
\hline Nets Loans & 1481483 & 1515302 & 1654258 & 1833138 & 2068968 & 2653211 & 2933754 & 3542050 \\
Deposits & 2105033 & 2357745 & 2912665 & 3399840 & 4418279 & 4684350 & 5078062 & 6163329 \\
Banking Net Proceeds & 255000 & 258030 & 284296 & 314414 & 378659 & 483588 & 478191 & 478909 \\
General Expenses & 75423 & 77716 & 87628 & 93998 & 106805 & 134674 & 152471 & 156610 \\
PersonnalExpenses & 65500 & 66295 & 69104 & 75946 & 87307 & 104293 & 108917 & 107346 \\
Net Operating Profit after Tax & 65730 & 83793 & 101714 & 106782 & 144671 & 159828 & 118273 & 123234 \\
Number of Banks & 32 & 33 & 33 & 38 & 39 & 43 & 45 & 43 \\
\hline
\end{tabular}

Sources.Authorsfrom BEAC Documents. \pm all other data but the 'numer of banks' are in millions of CFA francs (Communauté Financière Africaine).

We note that the netope rating profit after taxand the banking net proceedshave the same trend of evolution. It is 
translated by apositive growth rate of 7 to 8 years of study. But it was negativein 2009. During this period, the operating expenses including the general expenses and salaries and fringe benefits experienced a positive growth. On the other hand, the ratio netloans/deposits; which is an indicator of the strength of the banking intermediation ratio, has steadily declined from $70.3 \%$ in 2003 to $57 \%$ in 2010 . All these finding sunderp in the study of the influence of competition on the efficiency of banks in the CEMAC.

\section{Research Methodology}

\subsection{Efficiency Scores Measurement}

To measure the efficiency scores, there is need first of all to identify the inputs and outputsof the banking system of the CEMAC banking system, and calculate their prices. To this effect, we have followed the intermediation approach developed by Sealey and Lindley (1997); according to which the banking activity isa process of qualitative transformation of assets. Thus, the bank transforms the deposits of agentswith financing capacity into loans for agents in need of funding. Following this approach, one identifies 03 inputs namely, capital, labor, deposits and an outputconsisting of the total assets (Coccorese \& Pellecchia, 2010; Färeet et al., 2010; Koetter et al., 2011). Table 2 shows the prices of inputs and outputs as well as the total cost and profit before tax. These all form variables measuring efficiency scores.

Table 2. Variables for calculating efficiency scores

\begin{tabular}{llllll}
\hline Wording & Price & obs & average & minimum & maximum \\
\hline Labor (W1)\# & Personnel expenses / Number of employees & $48 \neq$ & 11,65 & 5,723 & 21,772 \\
Deposits(W2)\# & Interestexpenses / Total deposit & 48 & 0,01367 & 0,0033 & 0,03844 \\
Capital (W3)\# & Other operational costs / Immobilization costs & 48 & 0,1513 & 0,0042 & 1,1367 \\
Total assets (Y) \pm & Interest revenue and out of interest / Total assets & 48 & 818837,5 & 49000 & 291650 \\
Total cost & & 48 & 35743,73 & 2887 & 141185 \\
Profit & & 48 & 17986,27 & 1050 & 60025 \\
\hline
\end{tabular}

Source: Authors from COBAC Database. \# inputs, \pm output, $\neq 48=6$ countries under the CEMACx 8years! in millions.

The translog specification of ourcost function with three inputs and one outputis as follows (Devezeaux et al., 1990; Heyer et al., 2004):

$$
\begin{gathered}
\ln C_{i t}=\alpha_{0}+\alpha_{1} \ln Y_{i t}+\sum_{h=1}^{3} \alpha_{h} \ln w_{h i t}+\alpha_{T} \ln T r e n d+\frac{1}{2}\left\{\alpha_{Y Y}\left(\ln Y_{i t}\right)^{2}+\sum_{h=1}^{3} \sum_{K=1}^{3} \alpha_{h K} \ln W_{h i t} \ln W_{K i t}+\alpha_{T T}(\ln T r e n d)^{2}\right\} \\
+\sum_{h=1}^{3} \alpha_{Y h} \ln Y_{i t} \ln W_{h i t}+\alpha_{T Y} \ln \text { Trend } \ln Y_{i t}+\sum_{h=1}^{3} \alpha_{T h} \ln T r e n d \ln W_{h i t}+v_{i t+}
\end{gathered}
$$

Where $\ln$ is the logarithm, Cit the total cost, $\mathrm{i}=1, \ldots, \mathrm{N}$ is the country index, $\mathrm{t}=1, \ldots, \mathrm{T}$ the time index, $\mathrm{Y}$ is the output, $\mathrm{W}_{\mathrm{h}}$ the price factors of the inputs and the Trend. Measured by the funds themselves, the trend permits the account of changes in production techniques. $v_{-}$(it) $u_{i t}$ represent the random error and inefficiency term. The estimated profit efficiency follows the same logic, except that you write $\ln \left(\pi_{i t}+\theta\right)=\ln C_{i t}$; with $\theta>0$. The estimation of efficiency is equivalent to maximizing the function of the following probability (Aigner et al., 1977):

$$
\ln L=\frac{N}{2} \ln \frac{2}{\pi}-N \ln \sigma-\frac{1}{2 \sigma^{2}} \sum_{i=1}^{N} \varepsilon_{i}^{2}+\sum_{i=1}^{N} \ln \left[\Phi\left(\frac{\varepsilon_{i} \lambda}{\sigma}\right)\right]
$$

$\mathrm{N}$ is the number of countries, $\varepsilon_{i}=v_{i}+u_{i}, \sigma^{2}=\sigma_{v}^{2}+\sigma_{u}^{2}, \lambda=\frac{\sigma_{u}}{\sigma_{v}}, \Phi($.$) is the repartition function. The$ parameterization $\lambda=\frac{\sigma_{u}}{\sigma_{v}}$ is considered as a measure of the relative variability of the two sources of inefficiency. The efficiency scores are calculated with the help of the efficiency residual term $u_{i}$ by using the average (Jondrow et al., 1982). 
Table 3. The functions of cost and profit

\begin{tabular}{|c|c|c|c|}
\hline & parameters & $\ln C_{i t}$ & $\ln P_{i t}$ \\
\hline \multirow[t]{2}{*}{$\ln y_{i t}$} & $\alpha_{\mathrm{Y}}$ & 4.5542 & -2.9102 \\
\hline & & $(0.000)$ & $(0.631)$ \\
\hline \multirow[t]{2}{*}{$\ln \mathrm{W}_{1}$} & $\alpha_{1}$ & -2.4418 & 7.5651 \\
\hline & & $(0.077)$ & $(0.469)$ \\
\hline \multirow[t]{2}{*}{$\ln \mathrm{W}_{2}$} & $\alpha_{2}$ & -0.2443 & -6.9114 \\
\hline & & $(0.711)$ & $(0.155)$ \\
\hline \multirow[t]{2}{*}{$\ln W_{3}$} & $\alpha_{3}$ & -0.6192 & 2.5821 \\
\hline & & $(0.030)$ & $(0.229)$ \\
\hline \multirow[t]{2}{*}{ Lntrend } & $\alpha_{\mathrm{t}}$ & -1.1009 & 3.8098 \\
\hline & & $(0.104)$ & $(0.416)$ \\
\hline \multirow[t]{2}{*}{$\left(\ln y_{i t}\right)^{2}$} & $\alpha_{\mathrm{YY}}$ & -0.5643 & -0.9561 \\
\hline & & $(0.022)$ & $(0.517)$ \\
\hline \multirow[t]{2}{*}{$\operatorname{lny}_{\mathrm{it}} \ln \mathrm{W}_{1}$} & $\alpha_{\mathrm{Y} 1}$ & -0.2451 & -3.2916 \\
\hline & & $(0.316)$ & $(0.095)$ \\
\hline \multirow[t]{2}{*}{$\ln y_{i t} \ln W_{2}$} & $\alpha_{\mathrm{Y} 2}$ & 0.1624 & 1.2413 \\
\hline & & $(0.202)$ & $(0.156)$ \\
\hline \multirow[t]{2}{*}{$\operatorname{lny}_{\mathrm{it}} \ln \mathrm{W}_{3}$} & $\alpha_{\mathrm{Y} 3}$ & -0.0636 & -0.5253 \\
\hline & & $(0.376)$ & $(0.335)$ \\
\hline \multirow[t]{2}{*}{$\left(\ln W_{1}\right)^{2}$} & $\alpha_{11}$ & -2.0286 & 11.3955 \\
\hline & & $(0.011)$ & $(0.035)$ \\
\hline \multirow[t]{2}{*}{$\ln \mathrm{W}_{1} \ln \mathrm{W}_{2}$} & $\alpha_{12}$ & -0.4309 & 2.2881 \\
\hline & & $(0.005)$ & $(0.024)$ \\
\hline \multirow[t]{2}{*}{$\ln \mathrm{W}_{1} \ln \mathrm{W}_{3}$} & $\alpha_{13}$ & -0.018 & 0.5485 \\
\hline & & $(0.851)$ & $(0.488)$ \\
\hline \multirow[t]{2}{*}{$\ln W_{2} \ln W_{3}$} & $\alpha_{23}$ & -0.0957 & 0.0965 \\
\hline & & $(0.039)$ & $(0.770)$ \\
\hline \multirow[t]{2}{*}{$\left(\ln \mathrm{W}_{2}\right)^{2}$} & $\alpha_{22}$ & -0.0243 & 0.8805 \\
\hline & & $(0.878)$ & $(0.229)$ \\
\hline \multirow[t]{2}{*}{$\left(\ln W_{3}\right)^{2}$} & $\alpha_{33}$ & 0.0664 & -0.0481 \\
\hline & & $(0.055)$ & $(0.857)$ \\
\hline \multirow[t]{2}{*}{$(\operatorname{lntrend})^{2}$} & $\alpha_{\mathrm{tt}}$ & -0.5993 & -4.0924 \\
\hline & & $(0.021)$ & $(0.018)$ \\
\hline \multirow[t]{2}{*}{ lntrendlny $y_{i t}$} & $\alpha_{\mathrm{tY}}$ & 0.4418 & 2.5474 \\
\hline & & $(0.059)$ & $(0.091)$ \\
\hline \multirow[t]{2}{*}{ Intrend $\ln \mathrm{W}_{1}$} & $\alpha_{\mathrm{t} 1}$ & 0.7908 & 1.8401 \\
\hline & & $(0.000)$ & $(0.297)$ \\
\hline \multirow[t]{2}{*}{ lntrend $\ln \mathrm{W}_{2}$} & $\alpha_{\mathrm{t} 2}$ & -0.0568 & -0.9662 \\
\hline & & $(0.634)$ & $(0.153)$ \\
\hline \multirow[t]{2}{*}{ Intrend $\ln \mathrm{W}_{3}$} & $\alpha_{\mathrm{t} 3}$ & 0.1317 & 0.3175 \\
\hline & & $(0.110)$ & $(0.584)$ \\
\hline \multirow[t]{6}{*}{ cons } & A & -16.18051 & -18.2631 \\
\hline & & $(0.000)$ & $(0.292)$ \\
\hline & $\sigma$ & -2.947 & 5.4914 \\
\hline & 0 & $(0.008)$ & $(0.000)$ \\
\hline & $\lambda$ & 3.6651 & 7.83334 \\
\hline & & $(0.002)$ & $(0.000)$ \\
\hline \multirow{3}{*}{\multicolumn{2}{|c|}{ Log Likelihood Wald chi2(20) }} & 77.988 & -18.007 \\
\hline & & 8677.51 & 305.69 \\
\hline & & $(0.0000)$ & $(0.0000)$ \\
\hline
\end{tabular}

Source. Authors with Stata 11.

The average level of inefficiency is measured as the average of $u_{i}$, which is estimated as the average of $\hat{\varepsilon}_{i}$; with $\hat{\varepsilon}_{i}$ the estimated residue of the firm $i$ : since $u$ is independent of $v$ and $v$ follows a normal distribution with zero 
mean. The estimates give the functions of cost and profit in Table 3 .

What interests us most is $\lambda$ parameter; which is significantly different from zero forcost and profit efficiency with the SFA method. Due to its statistical properties, it indicates that thecost and profit inefficiencies exist. It then only remains toestimate it for each bank (country) using the equation (2). This phase isperformed automatically by Stata 11 andthe results are shownin Table 4 .

Table 4. Average levels of cost and profit efficiency

\begin{tabular}{cccccccc}
\hline & Cameroon & Central Africa Republic & Congo & Gabon & Guinea & Chad & CEMAC \\
\hline Profit efficiency & 32.84 & 40.97 & 78.34 & 24.23 & 24.46 & 25.63 & 37.74 \\
Cost efficiency & 97.29 & 96.95 & 81.84 & 97.73 & 98.68 & 83.16 & 92.60 \\
\hline
\end{tabular}

Source: Authorswith Stata11.

According to these results, it is possible for the CEMAC banks to reach their current level of production by reducing costs by $7.4 \%$ (from 100-92.60). Similarly, they may obtain additional profits of $62.26 \%$ (from 100 37.74 ) without changing the quantities of inputs and outputs. These inefficiency scores are slightly higher than those obtained by Koetter and Vins (2008) for German banks, Koetter et al. (2011) for the U.S., Florian (2012) for the UEMOA.

\subsection{Competition Measurement}

The Lerner index that we have used is defined as the difference between the average revenue, generally estimated by the output price and the marginal cost divided by the price. The price Pit is given by the price of output (total assets). It is biased because it assumes that banks are perfectly efficient against costs (Koetter et al., 2008). It is thus necessary to estimate the Lerner index from the average revenue and from the marginal cost obtained from an SFA analysis of the cost function. It is said to be adjusted that is, adjusted to the inefficiency.By definition, $L_{i t}=\frac{P_{i t}-\widehat{C M}_{i t}}{P_{i t}}=\frac{R M_{i t}-\widehat{C M}_{i t}}{R M_{i t}}$. Where $L_{i t}$ is the adjusted Lernerindex, Pitthe output price =average income $R M_{i t} \widehat{C M}_{i t}=\frac{\partial C_{i t}}{\partial Y_{i t}}$ is the marginalcost; estimated by the SFAmethod. The total revenue $=$ total cost + profit $\left(R_{i t}=\pi_{i t}+C_{i t}\right)$ andthe average total income=income/outputthe $\left(R M_{i t}=\frac{R_{i t}}{Y_{i t}}=\frac{\pi_{i t}+C_{i t}}{Y_{i t}}\right)$. Thus the adjusted Lernerindex:

$$
L_{i t}^{A}=\frac{\frac{\pi_{i t}+C_{i t}}{Y_{i t}}-\widehat{C M_{l t}}}{\frac{\pi_{i t}+C_{i t}}{Y_{i t}}}
$$

Where $L_{i t}^{A}$ is the adjusted Lerner index, $Y_{i t}$ the total output, $\pi_{i t}+C_{i t}$ and $\widehat{C M}_{i t}$ the cost, profit and margina lcost values estimated from the SFA approach. All these values are estimated automatically by Stata 11 and the results are shown in Table 5.

Table 5. Average level of adjusted lerner index

\begin{tabular}{ccccccc}
\hline & Cameroon & Central African Republic & Congo & Gabon & Guinea & Chad \\
\hline The Lerner adjusted & 42.29 & 65.25 & 46.89 & 75.645 & 69.68 & 71.73 \\
\hline
\end{tabular}

Source: Estimates with Stata 11.

Cameroon is acountry in which competition is very high; followed by the Congo. But our main concern is to assess to what extent this competition explains efficiency.

\subsection{Competition and Efficiency}

Apart from competition, several other variables are susceptible to influence banking efficiency. They are of two types: variables specific to banks and variables related to their environment. Variables specific to banks include: (i) diversification (DIV), which measures the effect of the extension of the scale of products offered by the bank on its efficiency.Its measure as proposed by Laeven and Levine (2007) is $D I V=1-\left|\frac{R I-R H I}{R T}\right|$ with RT the total income, RI the interest income and RHI the out interest income; (ii) the ratio of credits to total assets (CD_AS) measures the difference between the products and services offered by a bank and reflects the preference of investment of the bank between loans and yielding assets (Chen, 2009), (iii) the risk (RISK) is measured by loan 
intermediation ratio to deposits because the more a bank will have a significant intermediation activity, the more it will be exposed to the risk of non-recovery of loan funds.

Variables related to the environment of banks are: (i) the growth rate of GDP per capita (GDP) to reflect the general level of income. The expected sign is positive on the cost efficiency because countries with high per capita income may have more customers using banking products (Chen, 2009). (ii) The density of the population (POP_DEN) is captured by the number of inhabitants per square kilometer. The higher the density of the population, the less costly it becomes to offer banking services due to proximity: hence the positive effect on efficiency (Cocoresse \& Pellechia, 2010). (iii) Inflation (INF), which is an indicator of macroeconomic stability, affects the performance of the banking sector negatively (Chen, 2009) by an increase in costs: hence the reduction in cost efficiency. But its effect on profit is positive because it increases the interest revenues.

With 6 countries, 8 periods of observations and 6 variables, the panel model is strongly indicated. We formulate two equations corresponding to the cost efficiency and profit efficiency, successively.

$$
\begin{aligned}
& \text { efficout }_{i t}=a_{0}+a_{1} L^{A}{ }_{i t}+\sum_{i=1}^{6} \beta_{i} Z_{i t}+\omega_{i t} \\
& \text { effiprofit }{ }_{i t}=a_{0}+a_{1} L_{i t}^{A}+\sum_{i=1}^{6} \beta_{i} Z_{i t}+\omega_{i t}
\end{aligned}
$$

Where efficout ${ }_{i t}$ is thecostefficiencyof the country $\mathrm{i}$ in the year $\mathrm{t}$; efficout ${ }_{i t}$ is theprofitefficiency of the country $\mathrm{i}$ and the year $\mathrm{t} ; Z_{i t}$ is the vector of variables of six variables identified above; $L^{A}{ }_{i t}$ is the measure of competition or the adjusted Lerner index; $\omega_{i t}$ the error term. But before estimating (4) and (5), two tests need to be carried out.

The first is that of the stationarity of the variables. We consider the unitary root test of the panel of Levin et al. (2002). It is based on the following two hypotheses. $\mathrm{H}_{0}$ : the panel contains a unitaryroot and $\mathrm{H}_{1}$ : the panelis stationary. The series is stationary if the p-value $<10 \%$. These tests show that the two panel sare stationary. The second test is that of the specification of errors $\omega_{i t}$. In the first step, Fisher's statistic permits the testing of the homogeneity; which is to determine whether it is reasonable to assume that the model (4) and (5) are exactly the same for all countries, or otherwise if there are specificities related to each country. To this end, we specify that $w_{i}=u_{i}+e_{i t}$ and test the two hypotheses, $\mathrm{H}_{0}: u_{i}=0$ against $\mathrm{H}_{1}: u_{i} \neq 0$. With Stata, these hypotheses are tested by effecting a regression of fixed effect models. If the p-value $<5 \%$, we reject $\mathrm{H} 0$. This was the case and we retained that there are country-specific individual effects. In the second step, we test whether these individual effects are fixed or random. We test the two hypotheses, $\mathrm{H}_{0}:=0$ against $\mathrm{H}_{1}: \sigma_{u}^{2} \neq 0$; where $\sigma_{u}^{2}$ denotes the variance of the error specific to the individual, $u_{i} \rightarrow N\left(0, \sigma_{u}^{2}\right)$. The test statistic is that of Breusch-Pagan. If Prob> Chi $2>5 \%$, we accept thenull hypothesis. In ourcase, the assumption of random individual effects is validated. The method of panels' estimation (4) and (5) is the Tobit regression.

\section{Results and Discussion}

The regression results between competition and cost efficiency, on the one hand, and between competition and efficiency profit, on the other, is shown on the annexes 2 and 3. The adjusted Learner index has a positive and significant effect ( $\operatorname{coef}=0.002, \mathrm{p}$-value $=0.000$ ) on the efficiency cost. This result shows that competition has a negative effect on cost efficiency. On the other hand, it has a negative and significant effect on profit efficiency $(-0.0087,0.000)$.

So, competition has a positive effect on profit efficiency. These results show that the effects of competition on efficiency are mixed in the CEMAC zone because they have an unexpected direction regarding cost efficiency. To explain these results, we are going to analyze how the theoretical transmission mechanisms of competition worked in the banking efficiency. They are either related to the environment of banks, or specific to those banks.

With regard to environmental variables, the actual GDP evolved in a decreasing rate of $6.6 \%$ in 2004 to $1.8 \%$ in 2009. Since it is a market variable, we are more interested in profit efficiency. One notes that a drop in the purchasing power has affected the efficiency profit negatively $(-0.0043,0.398)$; certainly by a drop in the consumption of banking products and economic activities in general. As we shall see it in the next paragraph, the ratio of credit/deposit went descending. Inflation on its part increased during the period of the study: its rate increased from $0.6 \%$ in 2004 to $4.2 \%$ in 2009 . As indicated in by literature, such a development plays against cost efficiency by a growth in bank costs $(-0.0028,0.34)$. But it works in favor of profit efficiency by an increase in the interest incomes $(0.020 ; 0.057)$.

The variable density of the population shows that in the most populated CEMAC countries, it is cheaper for banks to offer their services, but they have difficulty in satisfying the needs of all customers. For this reason, the high density of the population is in favor of cost efficiency $(0.00042,0.000)$, but unfavorable to the profit efficiency $(-0.002,0.000)$. 
As to the mechanisms specific to each bank, the strategy of diversification adopted in the CEMAC in the face of competition was to integrate the quality of loan applicants in the debtors' rates rather than sticking only to the duration. Thus the Global Effective Prime Rate of all the loans to the economy; according to the duration as wellas the quality of beneficiaries, was $7.31 \%$ for large enterprises, $12.36 \%$ for the Small and Medium enterprises (SMEs) and $14.91 \%$ for individuals (COBAC, 2010). This strategy favors the efficiency of banks and DIV variable positively explains profit efficiency $(0.0007095,0.801)$. In addition to diversification, the debtors' rates have generally increased from $14.5 \%$ in 2006 to $12.8 \%$ in 2008 , to $9.8 \%$ in 2009 and to 11.02 in 2010: thus a general downward trend. Meanwhile, deposit rates remained almost constant between $4.25 \%$ and $3.25 \%$. This situation is favorable to the profit efficiency, because it signifies that banks have made benefits even though they gave loans at lower prices against the costs which remained constant. But the constant rate of creditors reflects the inability of banks to reduce other operating expenses to attract more savings: it thus plays against the efficiency cost.

Moreover, the first variable (CD_AS) which gives account of the performance of the channel by the volume of loans to the economy explains, but in a marginal way, cost efficiency $(-0.0001246,0.45)$ and profit efficiency $(0.00007095,0902)$. This means that competition has not significantly changed the preference of banks for loans, in relation to other asset items. It rather led banks to intensify asset items in relation to the modernization of the means of communication and payment (COBAC, 2010). The ratio of loans/deposits has continued to deterioratein this zone; and its value which was 0.73 in 2003, was only 0.57 in 2010. This explains the over-banking liquidity in this zone. Because of this evolution, the variable RISK is unfavorable to the profit efficiency $(-0.013,0.000)$ because banks had opportunities to increase their profits by granting more credits.

\section{Conclusion and Recommendations}

The objective of this study was to analyze the effect of competition on cost efficiency and profit efficiency of banks in the CEMAC zone over the period 2003-2010. The stochastic frontier approach (SFA) has enabled the authors to estimate the cost and profit functions, and to obtain the efficiency scores and the levels of competition by the adjusted Lerner index. The Tobit regression shows that a high level of competition is rather related to inefficiency cost, while it is on the contrary associated with greater profit efficiency.

The analysis shows that the decline in the rates of debtors and the diversification of banking products are the mechanisms of the transmission effects of competition which worked during the period of this study. Notwithstanding, the ratios loans / deposits and deposit rates decreased. This was contrary to expectations. Inflation increased and GDP per capita decreased. This phenomenon penalized the transmission of the effects of competition on efficiency. We recommend a better control of inflation, policies to promote economic growth, and a greater diversification of banking products such as accompanying measures of banking competition in the CEMAC zone.

\section{References}

Aigner, D. J., Lovell, C. A. K., \& Schmidt, P. (1977). Formulation and estimation of stochastic frontier production functions. Journal of Econometrics, 6, 21-37. http://dx.doi.org/10.1016/0304-4076(77)90052-5

Baumol, J. C., Panzar, R., \& Willig, R. D. (1982). Contestable markets and the theory of industry structure. Harcourt Brace Jovanovich, Academic press.

Baltensberger, E., \& Dermine, J. (1992). European banking: prudential and regulatory issues. In Dermine (Ed.), Europeaan banking in the 90s. Basil Blackwell, Oxford.

Battese, G., \& Coelli, T. (1992). Frontier production functions, technical efficiency and panel data: with application to paddy farmers in India. Journal of Productivity Analysis, 3(1), 153-169. http://dx.doi.org/10.1007/BF00158774

Battese, G., \& Coelli, T. (1995). A model for technical inefficiency effects in a stochastic frontier production function for panel data. Empirical Economics, 20(2), 325-332. http://dx.doi.org/10.1007/BF01205442

BEAC. (2002). Rôle et fonction d'une banque centrale à l'ère de la globalisation. Colloque du Trentenaire de la Banque des États de l'Afrique centrale (BEAC).

Berger, A., \& Hannan, T. (1998). The efficiency cost of market power in the banking industry: A test of the "quiet life" and related hypotheses. Review of Economics and Statistics, 80(3), 454-465. http://dx.doi.org/10.1162/003465398557555

Berger, A., \& Humphrey, D. (1997). Efficiency of financial institutions: international survey and directions for future research. European Journal of Operational Research, 98(2), 175-212. 
http://dx.doi.org/10.1016/S0377-2217(96)00342-6

Berger, A., \& Mester, L. (1997). Inside the black box: what explains differences in the efficking and finance,of financial institutions? Journal of Banking \& Finance, 21(7), 895-947. http://dx.doi.org/10.1016/S0378-4266(97)00010-1

Berger, A. N., Hunter, W. C., \& Timme, S. G. (1993). The efficiency of financial institutions: A review and preview of research past, present and future. Journal of Banking and Finance, 17, 221-249. http://dx.doi.org/10.1016/0378-4266(93)90030-H

Bikker, J. A., \& Haaf, K. (2000). Measures of competition and concentration in the banking industry: a review of the literature. De Nederlandsche Bank Research Series Supervision no. 27.

Bikker, J., \& Haaf, K. (2002). Competition, concentration and their relationship: an empirical analysis of the banking industry. Journal of Banking and Finance, 26, 2191-214. http://dx.doi.org/10.1016/S0378-4266(02)00205-4

Brou, E. (2010). Développement financier, croissance économique et productivité globale des facteurs en Afrique Sub-Saharienne. African Development Review, 22(1), 23-50. http://dx.doi.org/10.1111/j.1467-8268.2009.00227.x

Casu, B., \& Girardone, C. (2009). Testing the relationship between competition and efficiency in banking: A panel data analysis. Economics Letters, 105, 134-137. http://dx.doi.org/10.1016/j.econlet.2009.06.018

Cetorelli, N. (1999). Competitive analysis in banking: appraisal of the methodologies. Federal Reserve of Chicago, Economic Perspectives, 1, 2-15.

Chen, C. (2009). Bank efficiency in Sub-Saharan African middle-income countries. IMF Working Paper, 09/14:1-34. http://dx.doi.org/10.5089/9781451871616.001

Chen, X., Skully, M., \& Brown, K. (2005). Banking efficiency in China: Application of DEA to pre- and post-deregulation eras: 1993-2000. China Economic Review, 16, 229-245. http://dx.doi.org/10.1016/j.chieco.2005.02.001

Chiappori, P. A., \& Yanelle, M. O. (1996). Le risque bancaire: un aperçu théorique. Revue D'Économie Financière, 37, 97-111. http://dx.doi.org/10.3406/ecofi.1996.2268

Claessens, S., \& Laeven, L. (2004). What drives bank competition? Some international evidence? Journal of Money, Credit, and Banking, 36, 562-583. http://dx.doi.org/10.1353/mcb.2004.0044

COBAC. (2012). Evolution des Conditions de Banques dans la CEMAC (2006-2010). 4em réunion de concertation annuelle avec la profession bancaire et financière.

COBAC. (2011). Situation Du Système Bancaire Et Evolution Du Dispositif De Supervision Dans La Communauté Economique Et Monétaire De L'Afrique Centrale. 16ème assemblée annuelle du comite des superviseurs de banques de l'Afrique de l'ouest et du centre (Conakry, du 13 au15 décembre 2011).

COBAC. $(2007,2008,2009,2010)$. Rapport annuel des exercices.

Coccorese, P., \& Pellecchia, A. (2010). Testing the 'Quiet Life' Hypothesis in the Italian banking industry. Economic Notes, 39(3), 173-202. http://dx.doi.org/10.1111/j.1468-0300.2011.00227.x

Delis, M. D., \& Tsionas, E. G. (2009). The joint estimation of bank-level market power and efficiency. Journal of Banking and Finance, 33, 1842-1850. http://dx.doi.org/10.1016/j.jbankfin.2009.04.006

Dem, A. (2003). Economies de couts, économies d'échelle et de production jointe dans les banques de l'UEMOA: qu'est ce qui explique les différences de performance? BCEAO, Notes d'Informationet Statistiques 537.

Demsetz, H. (1973). Information and efficiency: Another viewpoint. Journal of Law and Economics, 10, 1-22. http://dx.doi.org/10.1086/466752

Devezeaux De Lavargne, J. G., Ivaldi, M., \& Ladoux, N. (1990). La forme flexible de fourier: une évaluation sur données macroéconomiques. Annalesd'Economieet de Statistique, 17, 121-144.

Diamond, D. (1984). Financial intermediation and delegated monitoring. Review of Economic Studies, July, 51. http://dx.doi.org/10.2307/2297430

Dietsch, M. (1992). Quel modèle de concurrence dans l'industrie bancaire? Revue Économique, 2, 229-260.

Fama, E. (1985). What's different about banks? Journal of Monetary Economics, 15(1), $29-39$. http://dx.doi.org/10.1016/0304-3932(85)90051-0 
Fouda, O. (2009). La surliquidité des banques en zone franc: comment expliquer le paradoxe de la CEMAC. Revue Africaine D'intégration, 3(2), 43-90.

Färe, R., Grosskopf, S., Maudos, J., \& Tortosa-Ausina, E. (2010). Efficiency and Market Power in Spanish Banking. 23rd Australasian Finance and Banking Conference 2010 Paper.

Farrell, M. (1957). The measurement of productive efficiency. Journal of the Royal Statistical Society. Series A (General), 120(3), 253-290. http://dx.doi.org/10.2307/2343100

Fouda, O. (2009). La surliquidité des banques en zone franc: Comment expliquer le paradoxe de la CEMAC? Revue Africaine de L'Intégration, 3(2), 43-90.

Florian, L. (2012). Effet de la concurrence sur l'efficience bancaire en Afrique: Le cas de l'UEMOA. CERDI, Etudes et Documents, 2.

Freixas, X., \& Rochet, J. (2008). Microeconomics of banking. MIT press Cambridge.

Hart, O. (1983). The market mechanism as an incentive scheme. Bell Journal of Economics, 74, 366-382. http://dx.doi.org/10.2307/3003639

Hauswald, R., \& Marquez, R. (2006). Competition and strategic information acquisition in credit markets. Review of Financial Studies, 19(3), 967-1000. http://dx.doi.org/10.1093/rfs/hhj021

Heyer, E., Pelgrin, F., \& Arnaud, S. (2004). Translogou Cobb-Douglas? Le rôle des durées d'utilisation des facteurs. Document de travail 2004-19 de la Banque du Canada.

Hicks, J. (1974). The crisis in keynesian economics. Oxford: Basil Blackwel.

Hughes, J. P., \& Mester, L. J. (2008). Efficiency in Banking: Theory, Practice, and Evidence. Prepared for the Oxford Handbook of Banking.

Humphrey, D., \& Pulley, L. (1997). Banks' responses to deregulation: Profits, technology, and efficiency. Journal of Money, Credit, and Banking, 29(1), 73-93. http://dx.doi.org/10.2307/2953687

Jondrow, C., Knox Lovell, C. A., Materov, I. S., \& Schmidt, P. (1982). On the estimation of technical inefficiency in the stochastic frontier production function model. Journal of Econometrics, 19(2-3), 233238. http://dx.doi.org/10.1016/0304-4076(82)90004-5

Kablan, S. (2007). Measuring bank efficiency in developing countries: The case of WAEMU. African Economic Research Consortium.

Kane, E. (1988). Interaction of Financial and Regulatory Innovation. American Economic Review, 78, 328-334.

Kamgna, S. Y., \& Dimou, L. (2008). Efficacité technique des banques de la CEMAC. MPRA.

Koetter, M., \& Vins, O. (2008). The Quiet Life Hypothesis in banking evidence from German savings banks. Working paper series: finance \& accounting.

Koetter, M., Kolari, J., \& Spierdijk, L. (2011). Enjoying the quiet life under deregulation? Evidence from adjusted lerner indices for us banks. The Review of Economics and Statistics.

Koetter, M., Kolari, J. W., \& Spierdijk, J. (2008). Efficient competition? Testing the quiet life of U.S. banks with adjusted Lerner indices. Proceedings of the 44th 'Bank Structure and Competition' Conference, Federal Reserve Bank of Chicago.

Laeven, L., \& Levine, R. (2007). Is there a diversification discount in financial conglomerates? Journal of Financial Economics, 85(2), 78-95. http://dx.doi.org/10.1016/j.jfineco.2005.06.001

Lerner, A. P. (1934). The Concept of monopoly and the measurement of monopoly power. The Review of Economic Studies, 1(3), 157-175. http://dx.doi.org/10.2307/2967480

Leibenstein, H. (1966). Allocative efficiency vs. X-efficiency. American Economic Review, 56, 392-415.

Levine, R. (1997). Financial development and Economic Growth: views and agenda. Journal of Economic Literature, 35(2), 688-726.

Maudos, J., \& De Guevara, F. (2007). The cost of market power in banking: social welfare loss vs. cost $\begin{array}{lllll}\text { inefficiency. Journal of Banking \& } & \text { Finance, 31(7), 2103-2125. }\end{array}$ http://dx.doi.org/10.1016/j.jbankfin.2006.10.028

Marquez, R. (2002). Competition, adverse selection, and information dispersion in the banking industry. Review of Financial Studies, 15(3), 90-120. http://dx.doi.org/10.1093/rfs/15.3.901 
Neuberger, D. (1997). Structure, Conduct and performance in banking markets. Thüne Series of Applied Economic Theory, (12).

Pruteanu-Podpiera, A., Weill, L., \& Schobert, F. (2008). Banking competition and efficiency: A micro-data analysis on the Czech banking industry. Comparative Economic Studies, 50, 253-273. http://dx.doi.org/10.1057/palgrave.ces.8100248

Schaeck, K., \& Čihák, M. (2008). How does competition affect efficiency and soundness in banking? New empirical evidence. ECB Working Paper Series No. 932, European Central Bank.

Sobreira, R. (2004). Innovations financiers et investissement. Le cas de la titrisation (pp. 115-129). Innovations, 2004/1, n1.

Rhoades, S., \& Rutz, R. (1982). Market power and firm risk: a test of the Quiet Life Hypothesis. Journal of Monetary Economics, 9, 73-85. http://dx.doi.org/10.1016/0304-3932(82)90051-4

Schmidt, K. M. (1997). Managerial incentives and product market competition. Review of Economic Studies, 64, 191-213. http://dx.doi.org/10.2307/2971709

Sealey, C. W., \& Lindley, J. T. (1977). Inputs, outputs, and a theory of production and cost at depository financial institutions. Journal of Finance, 32, 1251-1266. http://dx.doi.org/10.1111/j.1540-6261.1977.tb03324.x

Turk Ariss, R. (2010). On the implications of market power in banking: Evidence from developing countries. Journal of Banking and Finance, 34(4), 765-775. http://dx.doi.org/10.1016/j.jbankfin.2009.09.004

Weill, L. (2004). On the Relationship between competition and efficiency in the EU banking sectors. Kreditund Kapital, 37, 329-352.

Weill, L. (1998). Concurrence et efficience dans la banque. Revue Française D'économie, 13(2), 101-127. http://dx.doi.org/10.3406/rfeco.1998.1051

Williams, J. C. (2011). Risk management and macroprudential supervisory policies. Paper series at IDEAS.

\section{Appendix A}

\section{Competition and Cost Efficiency}

\begin{tabular}{|c|c|c|c|}
\hline $\begin{array}{l}\text { Random-effects tobit regression } \\
\text { Group variable: pays }\end{array}$ & $\begin{array}{l}\text { Number of obs } \\
\text { Number of groups }\end{array}$ & & $\begin{array}{r}48 \\
6\end{array}$ \\
\hline Random effects $u_{-} i \sim$ Gaussian & obs per group: & & $\begin{array}{r}8 \\
8.0 \\
8\end{array}$ \\
\hline Log likelihood $=247.14933$ & $\begin{array}{l}\text { wald chi2(7) } \\
\text { Prob > chi2 }\end{array}$ & & $\begin{array}{r}1857.63 \\
0.0000\end{array}$ \\
\hline
\end{tabular}

\begin{tabular}{r|rrrrrr}
\hline costeffi & Coef. & std. Err. & $\mathrm{z}$ & $\mathrm{P}>|\mathrm{z}|$ & [95\% Conf. Interva1] \\
\hline POP_DEN & .000427 & .0000125 & 34.21 & 0.000 & .0004026 & .0004515 \\
GDP & .0001702 & .0016368 & 0.10 & 0.917 & -.0030379 & .0033782 \\
INF & -.0028974 & .003077 & -0.94 & 0.346 & -.0089283 & .0031334 \\
CD_AS & -.0001314 & .0001682 & -0.78 & 0.435 & -.000461 & .0001982 \\
DIV & -.0010669 & .0007832 & -1.36 & 0.173 & -.0026019 & .0004681 \\
RISK & .0048853 & .0005113 & 9.56 & 0.000 & .0038832 & .0058873 \\
ajust_Terner & .0023391 & .0007482 & 3.13 & 0.002 & .0008727 & .0038056 \\
_Cons & .866378 & .0008521 & 1016.77 & 0.000 & .864708 & .8680481 \\
\hline /sigma_u & .0855965 & .0247099 & 3.46 & 0.001 & .037166 & .1340269 \\
/sigma_e & .0006997 & .000072 & 9.72 & 0.000 & .0005586 & .0008407 \\
\hline rho & .9999332 & .0000409 & & & .999787 & .9999807 \\
\hline
\end{tabular}

observation summary: 


\section{Appendix B}

\section{Competition and Profit Efficiency}

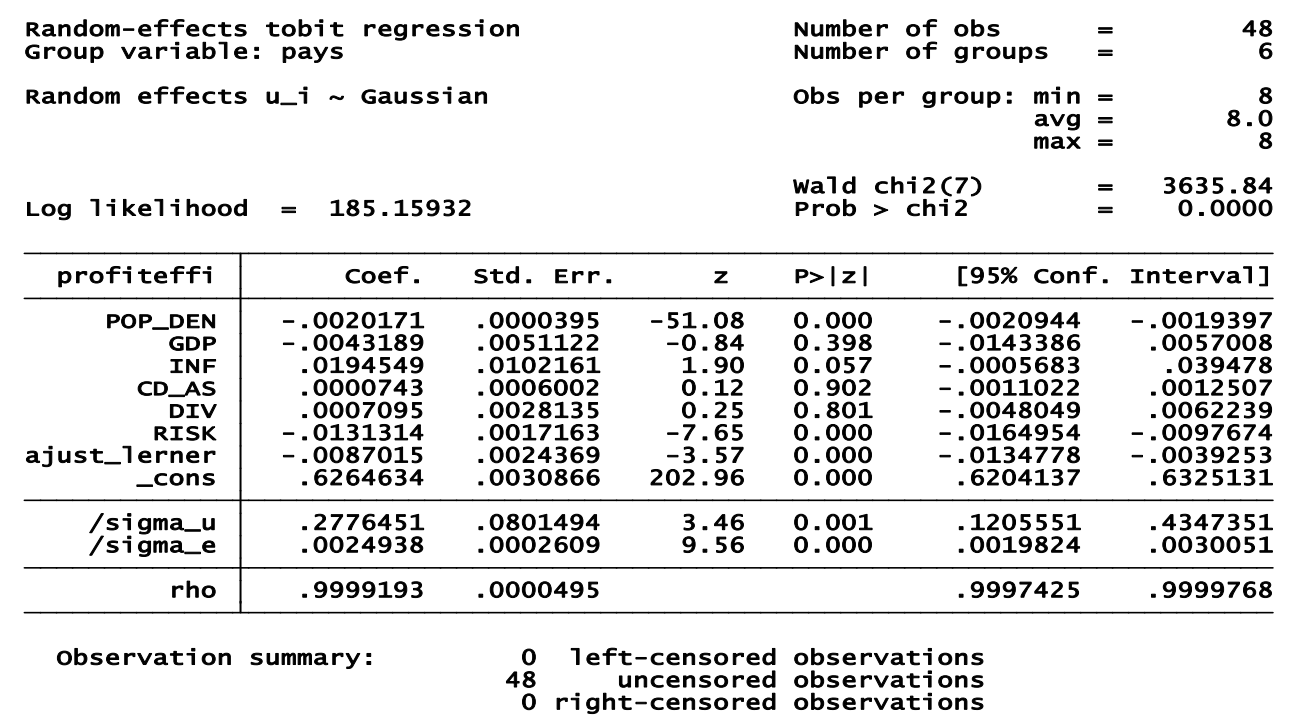

Source: Estimates with Stata11.

\section{Copyrights}

Copyright for this article is retained by the author(s), with first publication rights granted to the journal.

This is an open-access article distributed under the terms and conditions of the Creative Commons Attribution license (http://creativecommons.org/licenses/by/3.0/). 